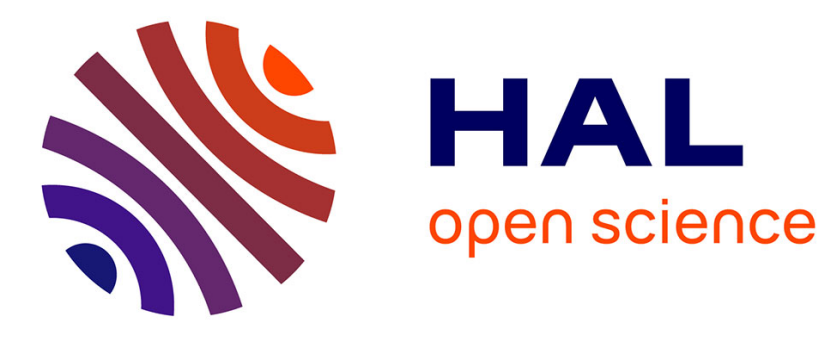

\title{
Origin of growth defects in pearl
}

Xavier Bourrat, Li Qiao, Qingling Feng, Martine Angellier, Aurore Dissaux, Jean-Michel Bény, Vincent Barbin, Philippe Stempflé, Marthe Rousseau, Evelyne Lopez

\section{- To cite this version:}

Xavier Bourrat, Li Qiao, Qingling Feng, Martine Angellier, Aurore Dissaux, et al.. Origin of growth defects in pearl. Materials Characterization, 2012, 72, pp.94-103. 10.1016/j.matchar.2012.07.010 . insu-00723037

\section{HAL Id: insu-00723037 https://hal-insu.archives-ouvertes.fr/insu-00723037}

Submitted on 3 May 2013

HAL is a multi-disciplinary open access archive for the deposit and dissemination of scientific research documents, whether they are published or not. The documents may come from teaching and research institutions in France or abroad, or from public or private research centers.
L'archive ouverte pluridisciplinaire HAL, est destinée au dépôt et à la diffusion de documents scientifiques de niveau recherche, publiés ou non, émanant des établissements d'enseignement et de recherche français ou étrangers, des laboratoires publics ou privés. 


\title{
Origin of growth defects in pearl
}

Xavier Bourrat $^{\text {abc }}$, Li Qiao ${ }^{\mathrm{d}}$ QingLing Leng ${ }^{\mathrm{d}}$ Martine Angellier ${ }^{\mathrm{abc}}$ Aurore Dissaux ${ }^{\text {abc }}$ Jean- $^{\text {- }}$ Michel Beny ${ }^{\text {abc }}$ Vincent Barbin ${ }^{\mathrm{e}}$ Philippe Stempfle ${ }^{\mathrm{f}}$ Marthe Rousseau $^{\mathrm{g}}$ Evelyne Lopez $^{\mathrm{h}}$

- ${ }^{\text {a }}$ Université d'Orléans, ISTO, UMR 7327, 45071 Orléans, France

- $\quad{ }^{\mathrm{b}}$ CNRS/INSU, ISTO, UMR 7327, 45071 Orléans, France

- $\quad{ }^{\text {c }}$ BRGM, ISTO, UMR 7327, BP 36009, 45060 Orléans, France

- ${ }^{\mathrm{d}}$ Tsinghua University, Department of Materials Science and Engineering, Beijing 100084, China

- ${ }^{\mathrm{e}}$ Reims Champagne-Ardenne University, GEGENAA, 2, Esplanade Roland-Garros, 51100 Reims, France

- $\quad{ }_{\mathrm{f}}$ Institute FEMTO-ST, ENSMM, 26 Chemin de l'Epitaphe, F-25030 Besançon Cedex, France

- ${ }^{\mathrm{g}}$ Nancy University, Physiopathology and Articular Pharmacology, 9 Avenue de la foret de Haye, BP 184, 54505 Vandoeuvre les Nancy, France

- ${ }^{\mathrm{h}}$ Museum National d'Histoire Naturelle USM 401-CNRS UMR7108, 43 rue Cuvier, 75231 cedex05 Paris, France

\begin{abstract}
Pearls are produced from a natural biomineralisation process. The structural unit is a biocrystal whose formation is controlled by organic molecules. In the present paper we studied a major growth defect to highlight the role of the organics in the growth mechanism. Some freshwater pearls exhibit a lack of lustre, also known as 'milky pearl' defect. This defect is related to the formation of vaterite instead of aragonite during the biomineralisation growth process. We used Rock Eval pyrolysis, a new technique in this field, to quantify a noticeable increase of the organic matrix in milky pearls. At least $20 \%$ more organics were found when vaterite forms than aragonite. To further study its role during the growth process, the organic matrix was extracted using three different protocols and characterised by infrared spectroscopy (FTIR) and liquid chromatography (HPLC). The fraction of the organic matrix which is soluble in water (WSM fraction) was significantly different when analysed by FTIR and by HPLC. This fraction is very likely occluded within the mineral (intracrystalline matrix). To examine its role, WSM extracted from milky pearls was used as additive in controlled calcium carbonate growth experiments. In this case, vaterite crystals were obtained for the greater part. When WSM extracted from healthy pearls was used, aragonite and calcite crystals were grown. The polymorph (vaterite $v s$ aragonite) appeared to be clearly connected to the WSM organic fraction. Several hypotheses may explain this result: e.g., a minor disorder of the organic composition of the extrapallial fluid, an excess of $\mathrm{Mn}$ or $\mathrm{Mg}$ or a blocking of the growth at a transient stage. Finally, we propose to use cathodoluminescence as a non-destructive technique to sort these defective pearls.
\end{abstract}

\section{Keywords}

- Biomineralisation;

- Vaterite;

- Aragonite;

- Cathodoluminescence;

- Rock Eval;

- HPLC; 


\section{- FTIR}

\section{Introduction}

Nacre, or mother of pearl, is a mineralised tissue that is produced to toughen the mollusc shell and increase its mechanical performance. Toughening is achieved by following the strategy of a dynamic multi-scale hybrid [1], where the organic matrix $(\sim 2.5 \mathrm{wt} . \%)$ controls the mineral deposit at a nanoscale ( $97.5 \mathrm{wt} . \%)$.

Freshwater pearls show a biomineralisation defect that is characterised by a lack of lustre (or 'milky' pearl). Ma and Lee [2] were the first to show that this defect was connected to the allotropic transformation of carbonate: hexagonal vaterite forms in place of orthorhombic aragonite [3]. Vaterite is the less stable allotropic form of crystallised anhydrous calcium carbonate. The structural and chemical aspects of this defect have been studied in detail [4], [5], [6] and [7]. In addition, the presence of vaterite has been observed in the centre of goodquality pearls [8] and other molluscan tissues [9] and [10].

In the present work, the organic matrix of the milky pearls was extracted and analysed by means of various techniques that compared it to the matrix of healthy pearls. It was then used in vitro as an additive [11] in a controlled growth experiment with calcium carbonate and compared with the matrix of healthy pearls under the same conditions.

\section{Experimental Section}

\subsection{Materials}

We were provided with regular and milky pearls from Zhuji, China. Hyriopsis cumingii is the most commonly used 'mussel' for pearl culturing in the south of China (Naiad of the Unionidae family). The milky pearls were sorted based on visual criteria. Powder was obtained by crushing both types of pearls using an agate mortar and a sieve. The powder produced from crushing the regular pearl is made up of pure aragonite. The powder obtained from the milky pearls is a mixture of aragonite and vaterite. It was not possible to find pearls made entirely of vaterite to obtain a pure vaterite powder. The composition of the powders was verified by FTIR (Fig. 1). The main peak is the $\mathrm{CaCO}_{3} v_{3}$ asymmetric stretching mode. This peak is split in two in the case of vaterite $\left(1490 \mathrm{~cm}^{-1}\right.$ and $\left.1420 \mathrm{~cm}^{-1}\right)$. The third peak (approximately $1470 \mathrm{~cm}^{-1}$ ) is the $v_{3}$ mode of aragonite. The same control measurement was obtained for all other peaks: $v_{4}$ at $750 \mathrm{~cm}^{-1}, v_{2}$ at $877 \mathrm{~cm}^{-1}$ and $v_{1}$ at 1088 and $1070 \mathrm{~cm}^{-1}$. The spectra also showed the presence of weak bands that were attributed to the organic matrix: a wide band at $1630-1660 \mathrm{~cm}^{-1}$ and a finer one at $1557 \mathrm{~cm}^{-1}$. These peaks are very likely the protein's amide I (stretching mode of $\mathrm{C}=\mathrm{O}$ peptide bonds, mainly) and amide II (more complex coupling of $\mathrm{C}=\mathrm{N}$ stretching and the $\mathrm{NH}$ twisting modes). 


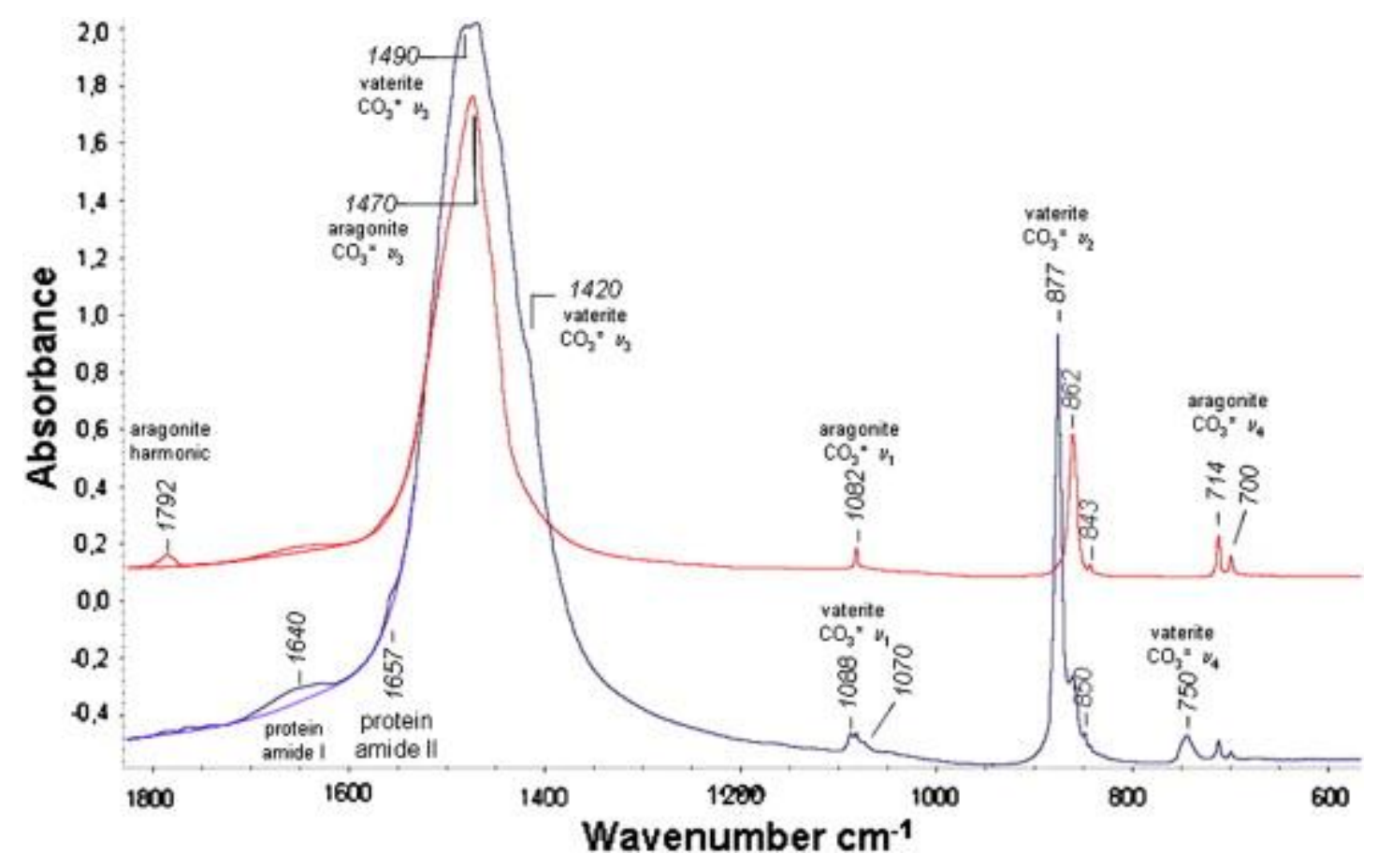

Fig. 1. FTIR spectra of regular (red) and milky pearls (blue). Regular pearls exhibit pure aragonite spectrum; milky pearls exhibit both vaterite and aragonite allotropes. Note the presence of the main protein modes at the foot of the $v_{3}$ carbonate peak.

The extraction of the organic matrix was conducted according to the flowchart in Fig. 2. The powder was mixed in a proportion of $25 \mathrm{~g}$ to $100 \mathrm{~mL}$ of Milli-Q water with stirring for $24 \mathrm{~h}$. The water-soluble matrix (WSM) was obtained by filtration according to the protocol described by Pereira-Mouriès et al. [12]. The water insoluble residue was then decarbonated in a strong acid $(\mathrm{HCl})$ using a $\mathrm{pH}$ metre bench set with a final point at $\mathrm{pH}=4$. At these conditions, the powders were never decarbonated at a $\mathrm{pH}$ lower than 4. The strong $\mathrm{HCl}$ acid is preferred to acetic acid or to EDTA, which are known complexing agents. Filtration allowed for the separation of the acido-soluble organic matrix (ASM) from the acido-insoluble matrix (AIM). 


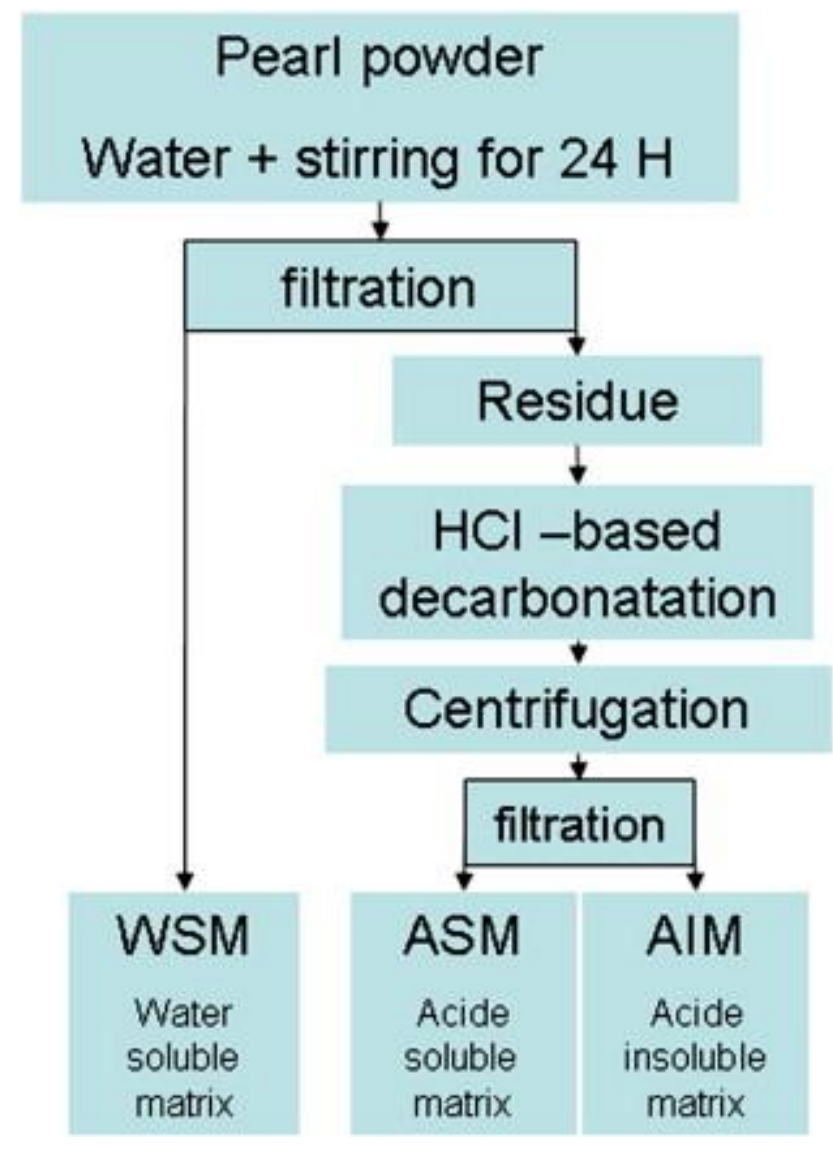

Fig. 2. Flowchart of the various organic fractions obtained from the two powders.

\subsection{Methods}

Polished thin sections were examined under a cold cathode luminescence instrument provided by OPEA (Laboratoire d'Optique Electronique Appliquee, Vincennes France) mounted on a metallographic microscope (Olympus, BX-50). A cold cathode source electron gun was chosen for its ability to produce a stable electron beam (intensity-current fluctuations $<1 \%$ ). Observations were carried out at an accelerating voltage of $15-20 \mathrm{keV}$ and an operating current of 250-400 $\mu \mathrm{A}$. Images were collected with a QUICAM Imaging Fast1394 digital camera in time integration mode using the Archimed Pro Microvision Instrument program. Spectra were obtained using a Carl Zeiss MMS1 UV/VIS spectrometer with fibre optic coupling mechanically mounted on the sample chamber. The instrument operates in the $0.3-$ $1 \mathrm{~mm}$ range with a $3.3 \mathrm{~nm}$ spectral resolution. The Carl Zeiss Aspect plus program was used. This technique is a very convenient tool for distinguishing calcite and aragonite [13].

Cathodoluminescence was also performed on a stereo binocular microscope (with similar chamber and conditions) to directly examine the surface of the pearl. This allowed us to identify vaterite at the surface of the pearl in a non-destructive manner.

The total organic carbon content (TOC) of nacre was measured by a programmed pyrolysis conducted in Rock Eval 6 Turbo from Vinci Technologies, France. This technique provided the amount of organic and mineral carbon present in the pearl powder (TOC and $\mathrm{C}_{\min }$, respectively). The technique requires an average over a statistical number of runs [14]. An analysis takes place in two steps: the first step is a pyrolysis and then there is an oxidation of 
the residue. Pyrolysis is conducted under nitrogen and starts by a desorption of volatiles at $200{ }^{\circ} \mathrm{C}$ for $5 \mathrm{~min}$. Then, it continues between 200 and $650{ }^{\circ} \mathrm{C}$ at $30{ }^{\circ} \mathrm{C} \mathrm{min}{ }^{-1}$. Three detectors record the nature of the effluents: a FID (flame ionisation detector) essentially sensitive to hydrocarbons and two infrared cells to measure $\mathrm{CO}$ and $\mathrm{CO}_{2}$. At low temperatures, mother-ofpearl shows the cracking of the organic matrix in the form of hydrocarbon and $\mathrm{CO}_{2}$, whereas at high temperatures, beyond $550{ }^{\circ} \mathrm{C}$, the pyrolysis continues with the departure of $\mathrm{CO}_{2}$ produced by the transformation reaction of the calcite in lime. The integration of the peaks supplies the part of carbon that results from the organic matrix and the one that results from the mineral phase. The residue of pyrolysis is then oxidised between $400{ }^{\circ} \mathrm{C}$ and $850{ }^{\circ} \mathrm{C}$ under artificial air $\left(\mathrm{N}_{2}: \mathrm{O}_{2}, 80: 20\right)$ in a second oven. $\mathrm{CO}$ and $\mathrm{CO}_{2}$ are registered, and the peaks are integrated to quantify the respective values of TOC and $\mathrm{C}_{\min }$. Each sample was treated from a test sample of $40 \mathrm{mg}$ and $100 \mathrm{mg}$ of powder. The small sample was used to obtain the $\mathrm{C}_{\mathrm{min}}$ value without IR cell saturation, and the large sample was used to increase the precision of the TOC value. To properly quantify $\mathrm{C}_{\min }$, it is necessary to program the second oxidation cycle between 400 and $850{ }^{\circ} \mathrm{C}$.

Infrared spectroscopy (FTIR) was monitored in the 4000-650 $\mathrm{cm}^{-1}$ wave number range with a spectral resolution of $4 \mathrm{~cm}^{-1}$ using a FT-IR Magna-IR 760 spectrometer. A mass of 0.5 to $2 \mathrm{mg}$ was finely crushed, blended and pressed with $\mathrm{KBr}$ to obtain pellets.

In vitro experimental growth of $\mathrm{CaCO}_{3}$ was conducted in the presence of the different organic matrices (WSMs) to evidence their possible control of polymorphism [11]. Calcium carbonate was deposited by slow diffusion of $\mathrm{NH}_{4} \mathrm{HCO}_{3}$ vapour into cell-culture dishes containing $3 \mathrm{~mL}$ of $2 \mathrm{mM} \mathrm{CaCl}_{2}$ solution in a closed desiccator for $3 \mathrm{~h}$ at $25^{\circ} \mathrm{C}$. WSMs were tested as additives with two concentrations: $50 \mathrm{mg} / \mathrm{L}$ and $100 \mathrm{mg} / \mathrm{L}$. Using this $\mathrm{CO}_{2}$-diffusion method, the average supersaturation retains a low level everywhere in the solution.

The morphologies and structures of $\mathrm{CaCO}_{3}$ deposition were observed using a transmission electron microscope, Philips/FEI CM20 at $200 \mathrm{kV}$ with an imaging point resolution of $0.27 \mathrm{~nm}$ and a $\mathrm{CCD}$ camera. The sample $\left(\mathrm{CaCO}_{3}\right.$ crystals $)$ is dispersed in alcohol using ultrasonication for few seconds. A droplet of the suspended particles is spread on Milli-Q water surface in a beaker. A holey carbon coated copper grid (200 mesh from EMS, Hatfield PA) is wet at the surface of the water and withdrawn vertically. The grid is dried under a lamp. The morphology of $\mathrm{CaCO}_{3}$ crystals was observed using scanning electron microscope (SEM, JEOL-1530). The glass slide at the bottom of the cell-culture dishes is cautiously removed and dried in an oven and then sputter-coated with gold/palladium alloy before examination. The observation of the vaterite/aragonite interface in cross section was conducted on fracture surfaces from freshly broken pearls. The crystallographic study was supported by the Mineralogy Database edited by David Barthelmy (http://webmineral.com/).

\section{Results and Discussion}

Serial thin sections cut from milky pearls show that vaterite develops in perfect continuity with aragonite. On the pearl of Fig. 3b, only the poles are made of aragonite: at the surface, the equatorial zone shows the characteristic milky aspect. The various sections show that the heart of the pearl was perfect (aragonite) at the origin. The defect appears at two thirds into the growth. It is also very clear that regular and defective nacre deposit simultaneously on the surface. This reversibility was previously observed [8]. These authors have evaluated the presence of vaterite in good-quality pearls, near the centre of the pearl. 

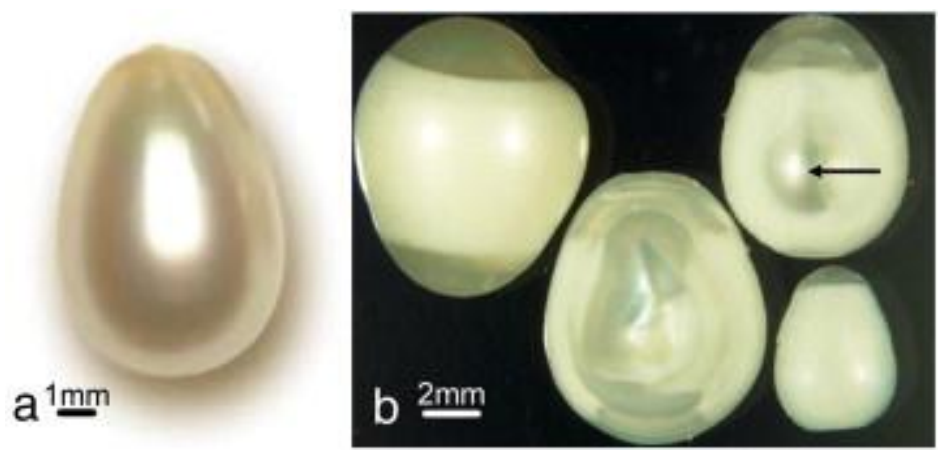

Fig. 3. Regular and milky pearls: (a) flawless or regular pearl, (b) serial thin sections cut from a single milky pearl: the equatorial zone is invaded by the defect (arrow: heart of good quality). (Optical micrograph).

Aragonite and vaterite deposit on the surface of the pearl simultaneously; this observation proves that the regular deposition mechanism remains unchanged or quasi unchanged.

Alternate mechanisms are known to occur in most of the mollusc shells. In Pinctada genus for instance, aragonite and calcite are generally found consecutively, i.e., one layer over the other, see for instance [15].

The examination of polished sections of milky pearls by means of cathodoluminescence confirms these observations: vaterite areas are in complete continuity with aragonite areas (Fig. 4a). Vaterite presents a strong orange-coloured spectrum with a maximum intensity at approximately $610 \mathrm{~nm}$ (Fig. 4b). Aragonite appears with a weaker signal in the green region at approximately $565 \mathrm{~nm}$ (Fig. 4c). Note the presence of a number of spurious peaks in both spectra: two intense peaks at approximately $400 \mathrm{~nm}$ and some at approximately $650 \mathrm{~nm}$ and $780 \mathrm{~nm}$. These peaks are fairly constant regardless of the measurement area. Very few data are published on the cathodoluminescence of vaterite. Sommer [16] detected minority phases as calcite or vaterite in the shells of aragonite. This result was confirmed by Barbin [17]. According to Sommer [18], vaterite emits at approximately $595 \mathrm{~nm}$. Béarez et al. [19] reported a broad emission centred at $700 \mathrm{~nm}$ for vaterite in an abnormal case of fish otolith. Our observations for vaterite indicate emissions at approximately $600-610 \mathrm{~nm}$ that are in agreement with the observations made by Sommer [16] but very different from those of Béarez et al. These authors did not address the luminescence of otolith's vaterite in their papers. The difference in the cathodoluminescence colour of calcite and aragonite is due to changes in the crystalline field parameters. In regard to vaterite, the magnitude of the shift could be due to structural distortions resulting from a higher concentration of $\mathrm{Mg}$ and $\mathrm{Mn}$ and a weaker concentration of $\mathrm{Na}$ and $\mathrm{Sr}$ in the vaterite lattice, as demonstrated by LA-ICP/MS (Laser Ablation-Inductively Coupled Plasma Mass Spectrometry) [8]. 

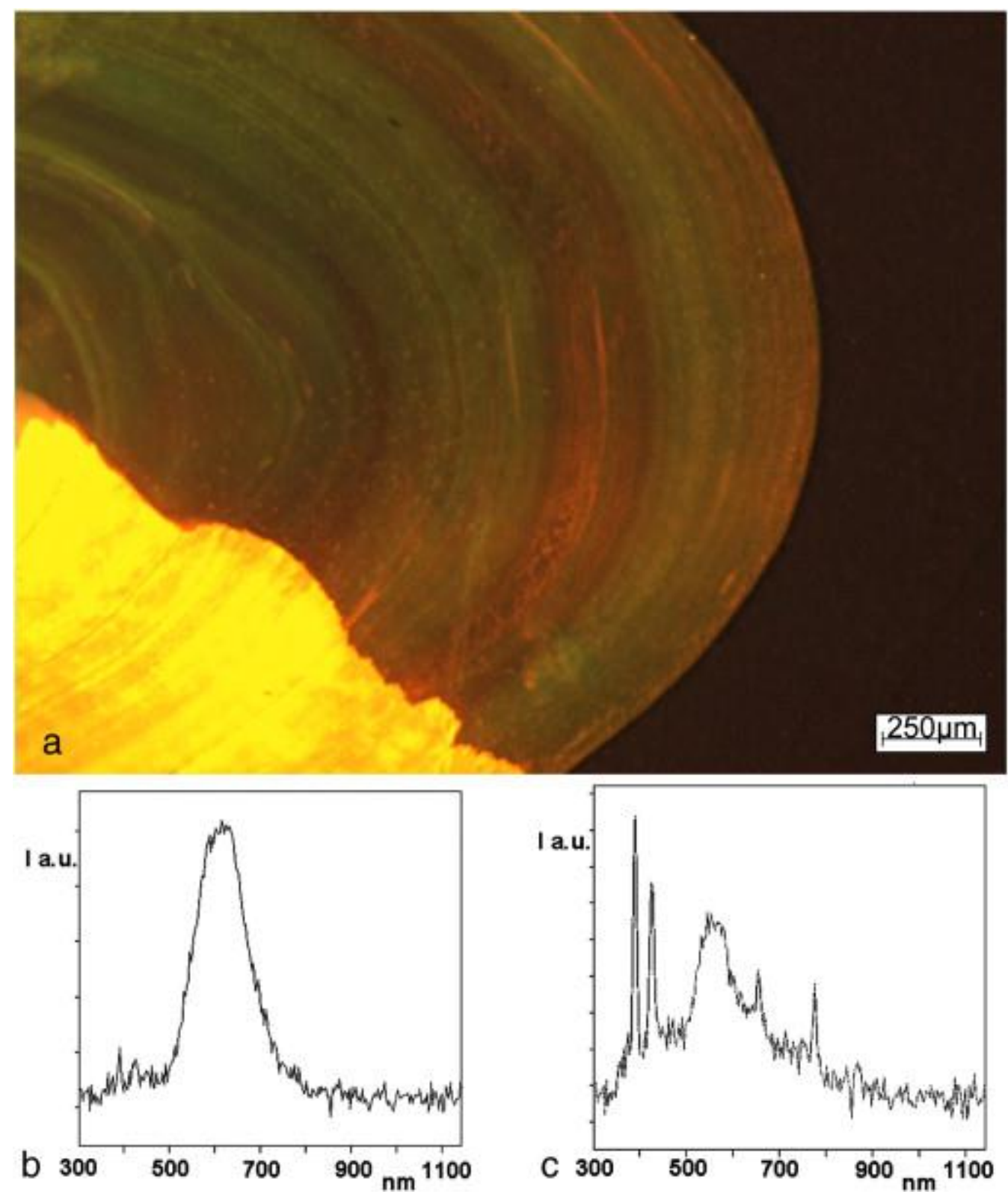

Fig. 4. Defect detection on a thin section of pearl by means of optical microscopy equipped with cathodoluminescence (CL). (a) Under electron beam, vaterite appears orange and aragonite dark green; (b) electroluminescence spectrum of vaterite characterised by a strong peak at approximately $610 \mathrm{~nm}$ and (c) weak electroluminescence of aragonite at $565 \mathrm{~nm}$. (Metallographic microscope equipped with a cold cathode source of electron).

The non-destructive observations of the surface of the pearls were performed using a binocular microscope equipped with the same stage. The results are shown in Fig. 5a. The dark green area corresponds to aragonite, and the orange area corresponds to vaterite. In the surface measurement procedure, the spectra were shifted to high wave numbers: the aragonite peak was weak but centred at approximately $570-580 \mathrm{~nm}$, while vaterite is intense at approximately $630 \mathrm{~nm}$. The shift observed for flat-on measurement at the surface regarding edge-on ones, in cross section, is attributed to interference phenomena due to the crystallographic orientation of the multilayered structure. 

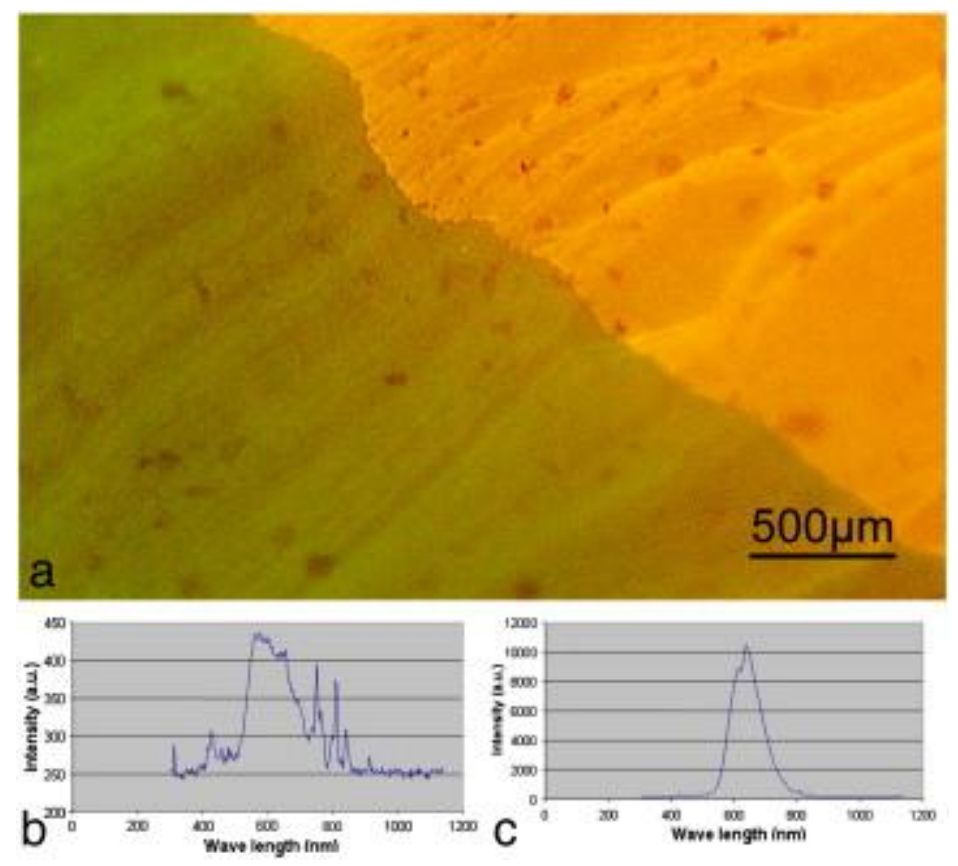

Fig. 5. Cathodoluminescence on a pearl surface. (a) Vaterite appears orange and aragonite appears dark green; (b) aragonite luminescence spectrum with a characteristic weak peak at 570-580 nm and (c) vaterite luminescence spectrum with a strong peak at $630 \mathrm{~nm}$. (Binocular microscope equipped with a cold cathode source of electron).

Milky pearls were broken to observe by SEM the interface between the normal and the milky zones (Fig. 6). The regular aragonite is present in the bottom right of the micrograph, and the milky nacre is in the top left. The milky nacre exhibits thinner tablets when viewed in cross section. Meanwhile, in a co-deposition area like this one, the amount of tablet is equivalent on both sides of the interface when a pile is considered. This implies the same compartment thickness regardless of the filling: i.e., aragonite or vaterite. 


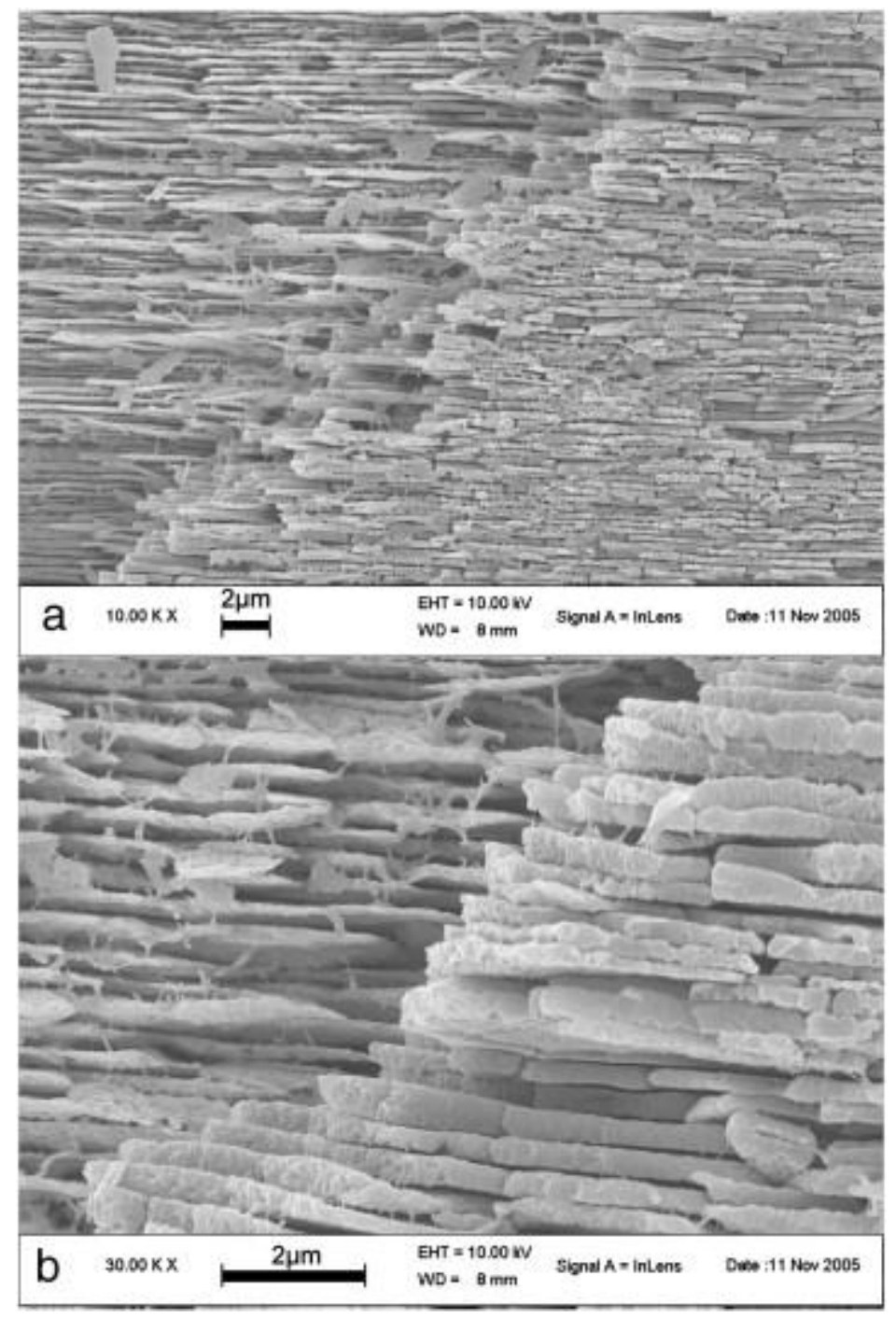

Fig. 6. SEM picture of a half milky pearl at the interface between vaterite (left) and aragonite (right). (a) Low magnification and (b) higher magnification of the same zone (secondary electron, in-lens detector).

Both powders were then handled by Rock-Eval programmed pyrolysis. The pyrograms showed in an indisputable way that the milky pearls contain a higher organic carbon concentration (TOC) compared to regular pearls. This was systematically confirmed in every analysis with variable rates according to the starting pearl powder: milky pearls are a blend of aragonite and vaterite. During programmed pyrolysis, the organic matrix first undergoes progressive cracking with an increase in temperature. This method was detailed in a previous paper regarding Pinctada margaritifera nacre [14]. Depending on the energy of the different bonds of proteins, polysaccharides and lipids, organic molecules progressively degrade by producing hydrocarbons, $\mathrm{CO}_{2}$ and $\mathrm{CO}$ molecules. Rock-Eval registers these 3 departures versus the programmed temperature: a flame ionised detector (FID) detects the hydrocarbons, and two IR cells detect the departure of mineral $\mathrm{CO}_{2}$ and $\mathrm{CO}$. As long as the temperature remains below $550{ }^{\circ} \mathrm{C}$ (so called 'low temperature'), these molecules are considered to be of organic origin. The degradation of the carbonate intervenes only at higher temperature, with the transformation first of aragonite and vaterite into calcite and then of calcite into lime 
(CaO) above $600{ }^{\circ} \mathrm{C}$ following different heat treatment conditions [5], [14] and [20]. This reaction occurs beyond 550 and until $940{ }^{\circ} \mathrm{C}$ in our conditions of pyrolysis. In this way, the different peaks occurring at low and high temperatures can be integrated to determine organic and mineral carbon, respectively.

At low temperature, thermograms (Fig. 7 and Fig. 8) showed the same features for the two powders. The comparison of the respective scales clearly shows that the amount of hydrocarbons released by the powder with vaterite is much higher. The integration of the various peaks showed a mean value of $21 \%$ more TOC in the powder obtained from the milky pearls than that obtained from the regular ones (4 analyses of the 2 powders). It was not possible to analyse pure vaterite-based powder; for that reason, this value is only indicative. Milky pearls have an indisputably higher organic content. Fig. 7 and Fig. 8 illustrate one example of each of the two extremes. The limit of $550{ }^{\circ} \mathrm{C}$ for vaterite correlates with previous observations using thermo-gravimetry in which milky pearls showed a higher thermal stability than regular ones [5]. Vaterite most likely recrystallises in a more stable hexagonal form as recently shown for inorganic vaterite by modelling [21]. In the case of milky pearls, we noted the appearance of a small peak at $475^{\circ} \mathrm{C}$ and the decline of the peak at $700{ }^{\circ} \mathrm{C}$ (yellow curve of Fig. 8). Both events are supposed to be specific features of vaterite. In conclusion, RockEval reveals the presence of an excess of organic carbon in the milky pearls, beyond the limits of the method's precision.

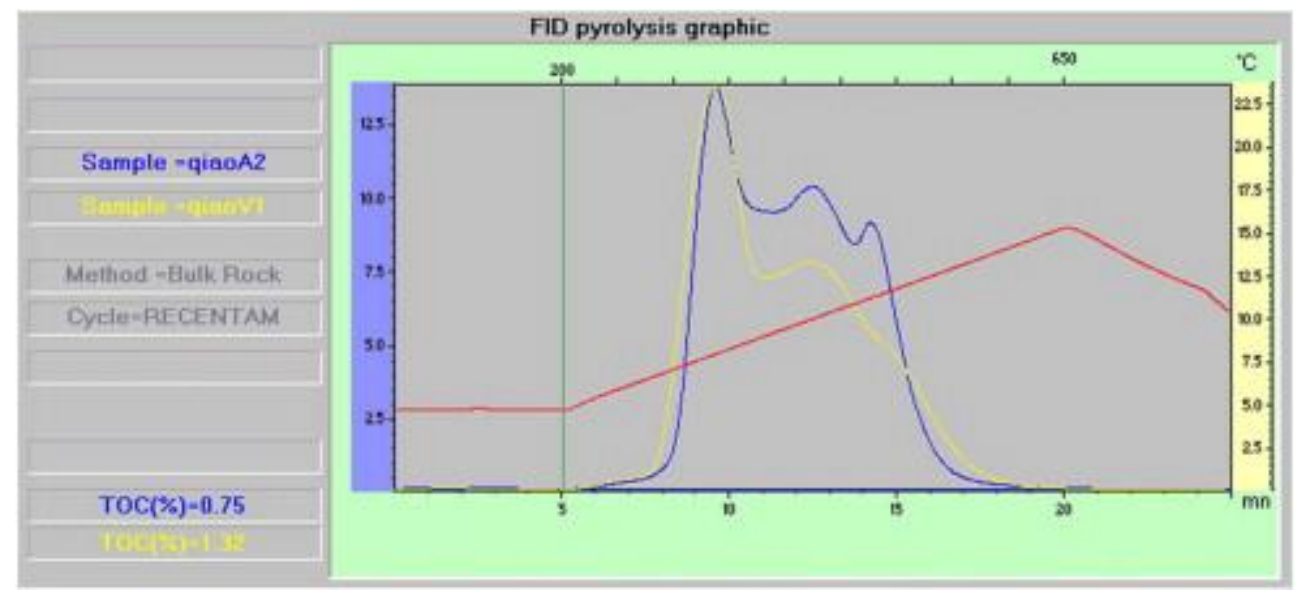

Fig. 7. Rock-Eval pyrolysis plots of regular (blue) and milky (yellow) pearl powders. The ordinate gives the quantity of hydrocarbons emitted per gramme of sample analysed (mg $\mathrm{Hc} / \mathrm{g}$, blue and yellow scales). The abscissa gives the time (min), and the curve in red indicates the temperature ramp between $200{ }^{\circ} \mathrm{C}$ and $650{ }^{\circ} \mathrm{C}$ (scale on top: ${ }^{\circ} \mathrm{C}$ ). 


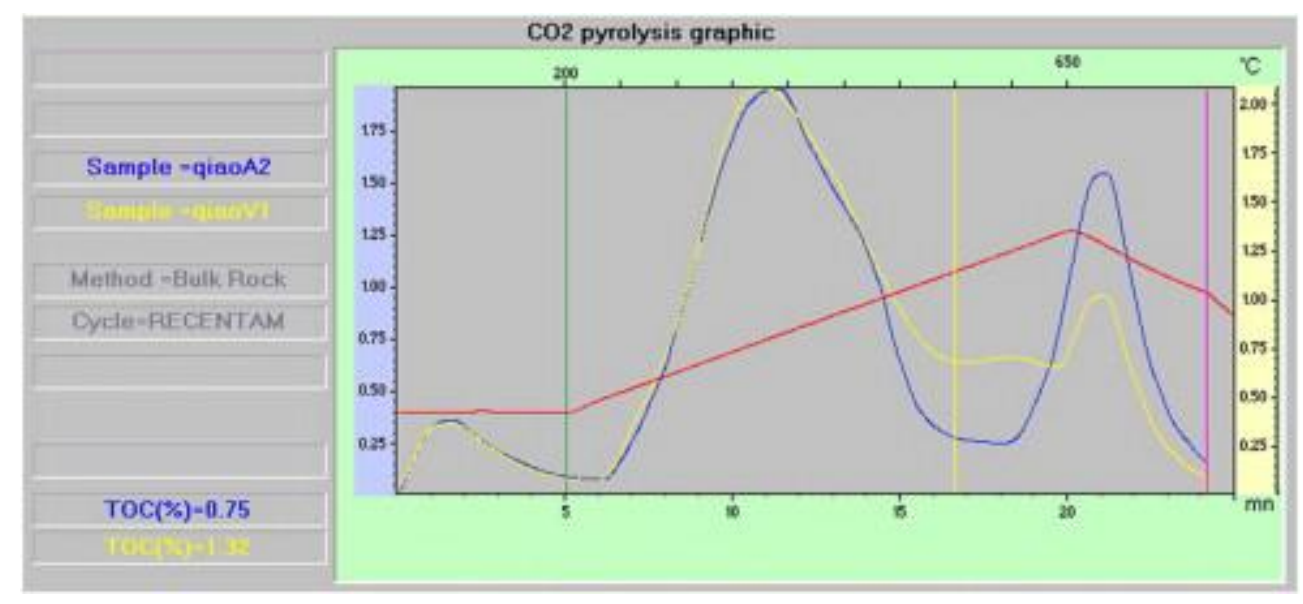

Fig. 8. Rock-Eval pyrolysis plots of regular (blue) and milky (yellow) pearl powders. The ordinate gives the quantity of $\mathrm{CO}_{2}\left(\mathrm{mg} \mathrm{CO}_{2} / \mathrm{g}\right.$ of sample, blue and yellow scale, respectively) produced during pyrolysis. The abscissa gives the time ( $\mathrm{min}$ ), and the red curve indicates the ramp of temperature. The limit of integration between the organic and the mineral $\mathrm{CO}_{2}$ was fixed at $550{ }^{\circ} \mathrm{C}$ (vertical yellow bar).

Analysis of the organic matrix fractions ASM, AIM and WSM was conducted after extraction following the flowchart shown in Fig. 2. The FTIR spectra of the 3 organic fractions were analysed and compared. There was no difference for the ASM and AIM fractions (Fig. 9). AIM is often attributed by the authors to chitin and glycoproteins, which are well known in nacre. These macromolecules are mainly involved in the intercrystalline and interlamellar zones between the tablets [22]. The ASM soluble fraction results from all of the compartments. The only differences appeared by comparing the two WSM extracts. The spectrum of the regular pearl was similar to the spectrum found for other bivalves, such as the Pinctada nacreous layer. In fact, only the WSM fraction of the milky pearls showed differences in comparison to all the other WSMs, mainly related to the abundance of peptides (Fig. 10). For example, primary and secondary amide bands appeared with very different ratios. A broadening of the band centred at $3300 \mathrm{~cm}^{-1}$ was in line with the larger abundance of peptide bonds (amide A). Peaks between 650 and $800 \mathrm{~cm}^{-1}$ could be attributed to out-of-plane N-H bending (amide VI). Finally, it was noticed that the $2560 \mathrm{~cm}^{-1}$ and $1925 \mathrm{~cm}^{-1}$ peaks have disappeared. 

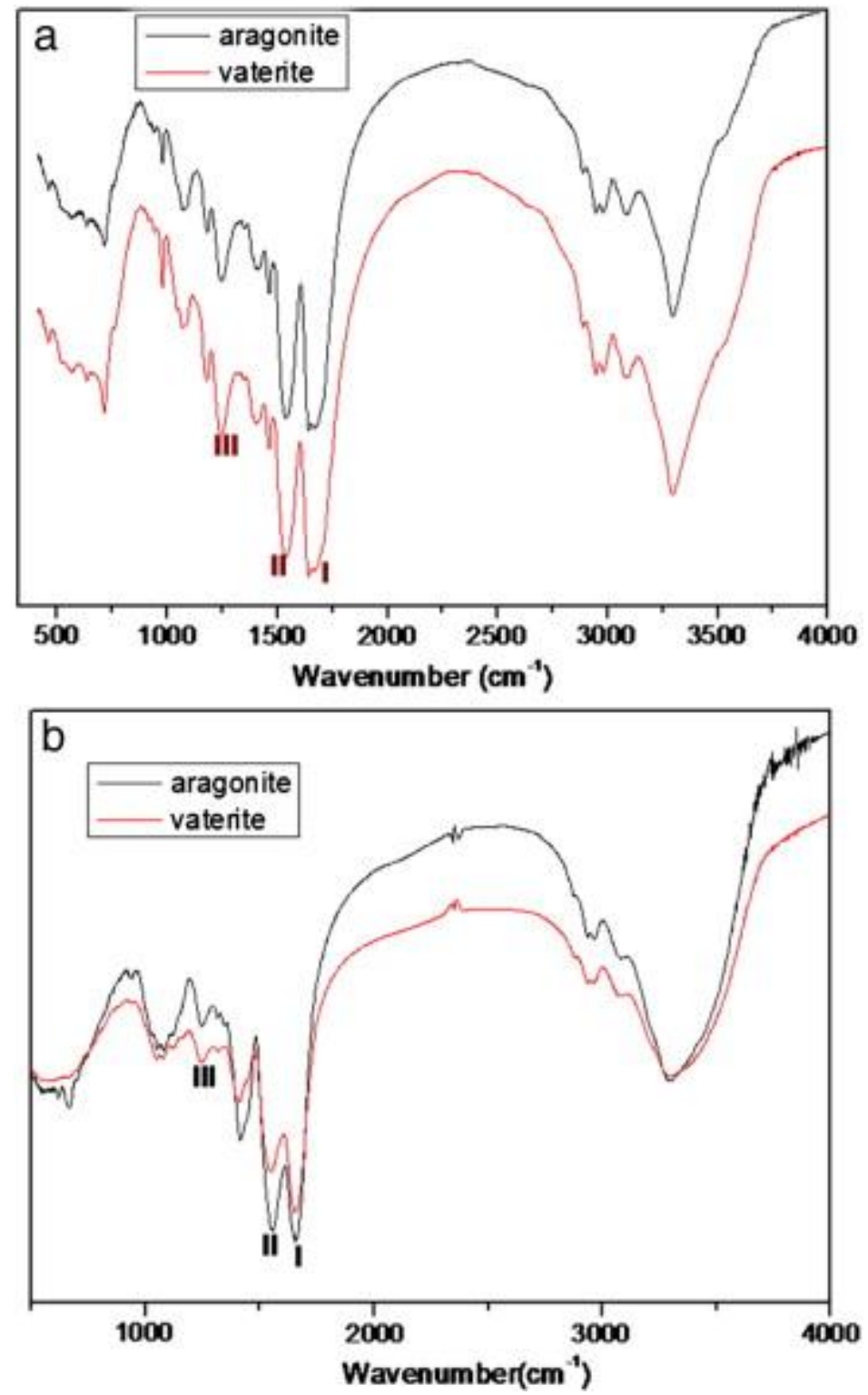

Fig. 9. FTIR spectra of the extracted fractions: (a) AIM and (b) ASM from regular (aragonite) and milky pearls (vaterite) (ordinate: relative transmittance, $\%$ ). 


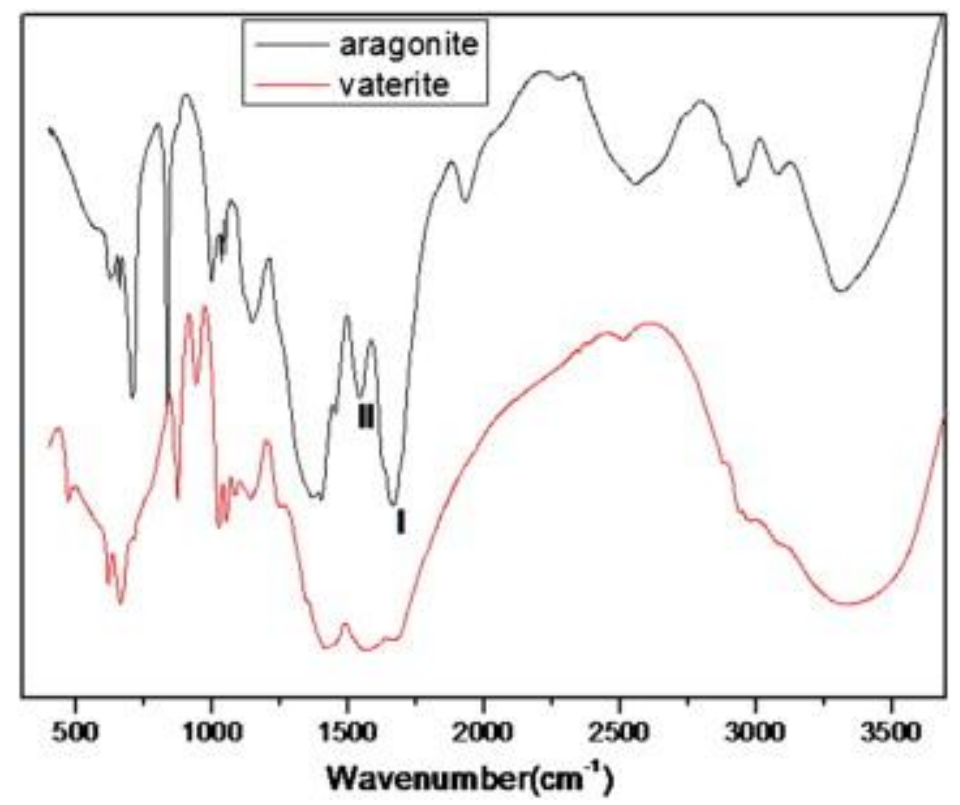

Fig. 10. FTIR WSM spectra: black, regular pearl (aragonite) and red, milky pearl (vaterite). WSM fractions exhibit different peak distributions (ordinate: relative transmittance, \%).

In summary, the FTIR analyses have shown that only the hydrosoluble matrix (WSM) extracted from the milky pearls presented peculiarities. These features can be interpreted as a strong abundance of peptide bonds. Based on the numerous works conducted on hydrosoluble fractions of nacre in our group, these molecules should be likely located in the intracrystalline matrix.

After extraction and freeze-drying, the WSM and ASM extracts were dissolved in ultra-pure water to analyse their protein content by steric exclusion chromatography. The profiles show significant differences for the WSMs but only abundance variations in the case of ASM (Fig. 11). As described in Pereira-Mouriès et al. [12], the hydrosoluble matrix can be separated peak by peak to conduct analyses. The plots in Fig. 11a show that the molecule distribution differed at short elution times, i.e., for large molecules of the WSM. Dauphin and Marin [23] were able to demonstrate a change of the protein and sugar distribution with the same technique on P. margaritifera affected by a nacre disease. In the case of ASM (Fig. 11b) the profile was the same, only the protein abundance changed: milky pearls are richer than regular ones. Reproducibility was good for all the HPLC analyses as shown on the example of Fig. 11b: two replica of each analysis are shown. In summary, chromatography has evidenced a higher amount of proteins in milky pearls than in regular ones. It has shown that only the hydrosoluble molecule distribution (WSM) changed when the vaterite defect appears. 

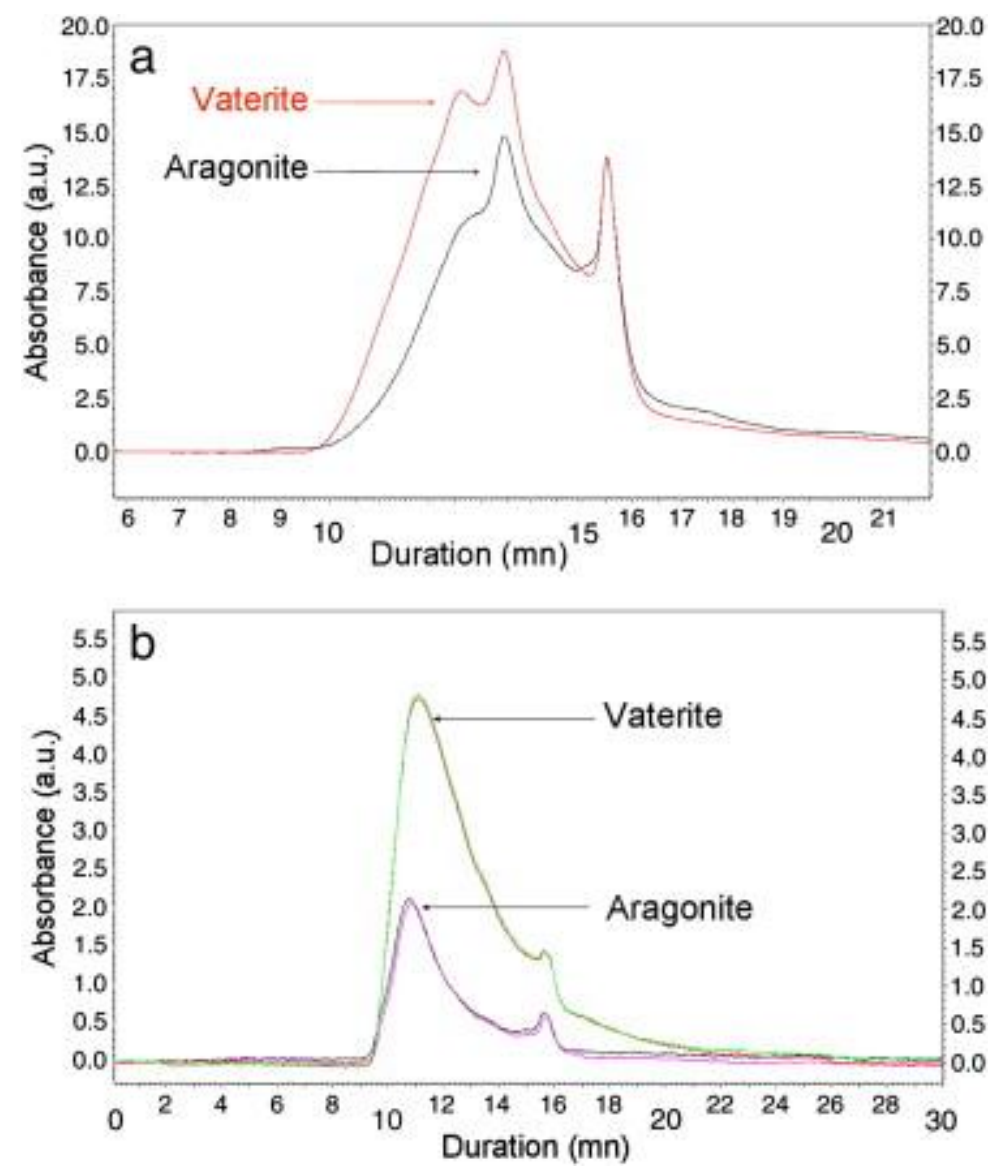

Fig. 11. HPLC plots (gel permeation, $226 \mathrm{~nm}$ UV detector) of (a) WSM fraction of regular (dark) and milky (red) pearl powders and (b) ASM fraction of regular (blue and purple) and milky (green and red) pearl powders.

In these last decades, controlled growth experiments have allowed the formation of vaterite by adding organic macromolecules [24], [25], [26] and [27]. Vaterite morphology often appears as spherical polycrystalline aggregates, but different morphologies were obtained due to the control of additives [28], [29] and [30]. To verify the role of the hydrosoluble matrix in the appearance of the defects, a controlled growth experiment was conducted in the presence of both WSM fractions. The particles grown were examined by SEM as shown in Fig. 12. Most of the crystals obtained in the presence of WSMara (extracted from the regular aragonite pearls) were crystals with typical needle-like morphology, attributed to aragonite (Fig. 12a). Crystals of calcite were also present. Crystals grown in the presence of WSMvat, the hydrosoluble matrix extracted from the milky pearls, were mostly vaterite crystals. When observed with SEM, vaterite crystals are characterised by their flat and hexagonal habitus (Fig. 12b). This characteristic was confirmed by transmission electron microscopy (Fig. 13) and electron diffraction mode (not shown). This classical observation was first reported by Falini et al. [31] and for ACC in ascidian by Aizenberg et al. [32]. 

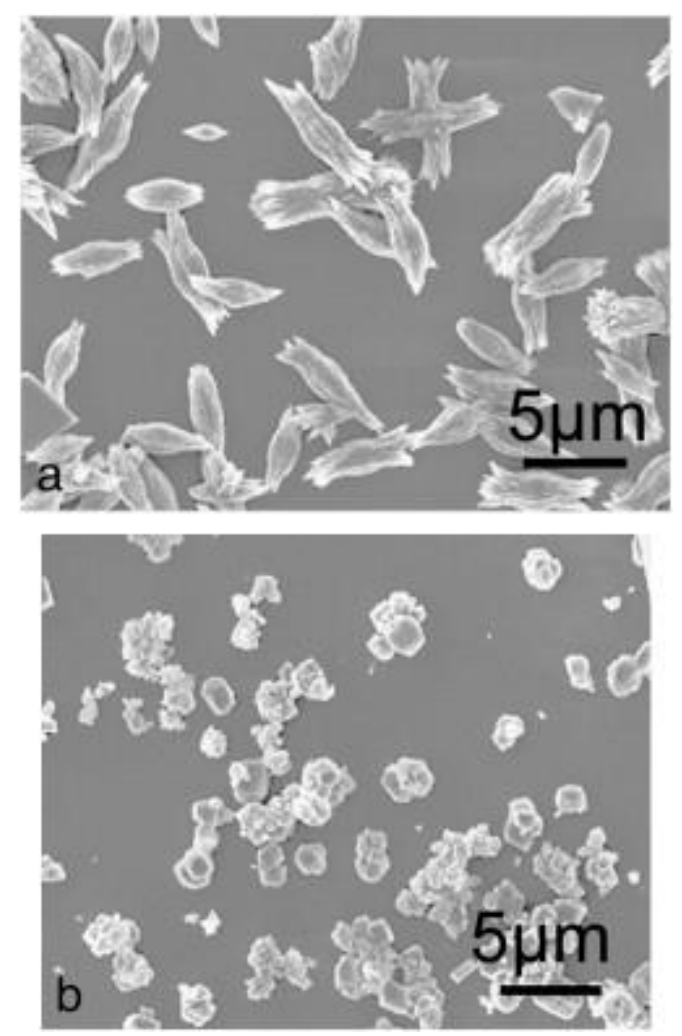

Fig. 12. Crystals grown with hydrosoluble extracts as additives: (a) aragonite needle-like crystals obtained with WSMara and (b) vaterite crystals (mainly) obtained with WSMvat as an additive (SEM secondary electron

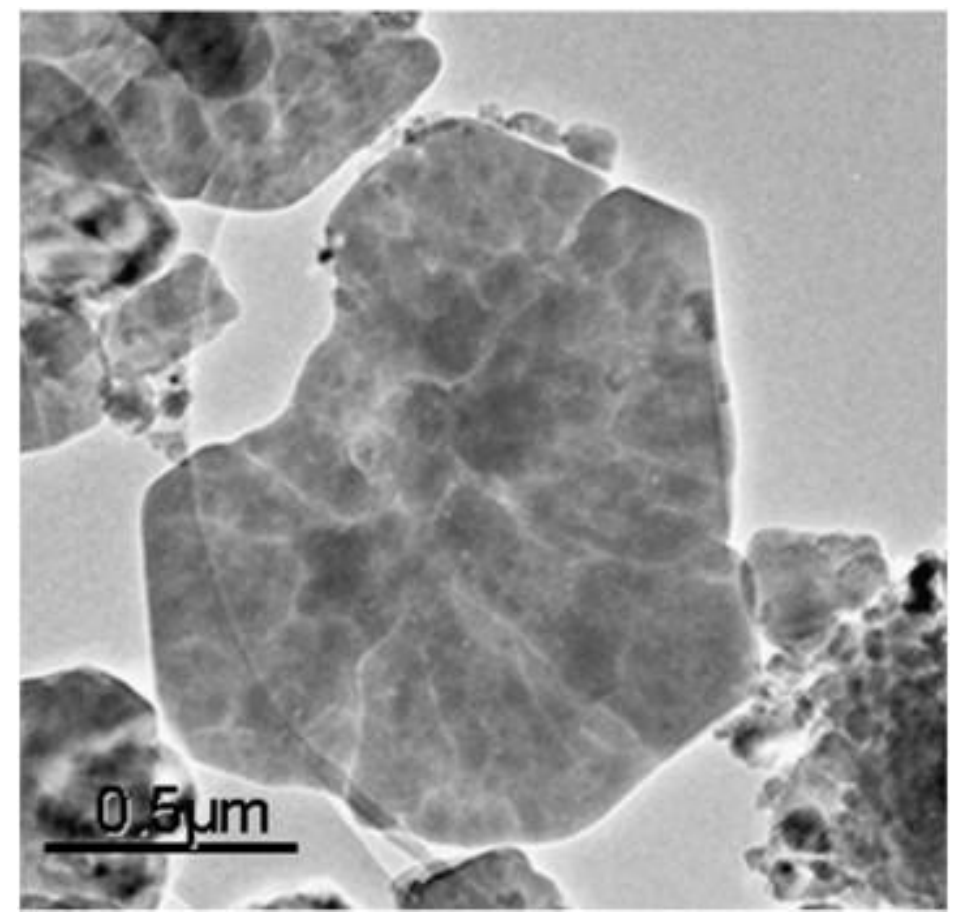

Fig. 13. Vaterite crystal grown with WSMvat as an additive, as seen by TEM (electron diffraction is not shown). 
During the growth of the crystal, oxygen-rich sites form onto faces perpendicular to the $\mathrm{c}$ axis. The authors suppose that certain proteins, specifically their acid groups, adhere to these sites and block the growth according to this axis. This mechanism was recently demonstrated by the addition of polyacrylic acid [33]. Even though the mechanism is not perfectly described, we can conclude, as have numerous authors, that the organic matrix associated with the crystal of calcium carbonate intervenes in the allotropic form, i.e., orthorhombic or hexagonal. In the case of the vaterite associated with the lacklustre pearl defect, even a weak amount of the organic matrix produces a powerful inhibitive effect. We did not find any aragonite crystals concomitantly grown with vaterite, as in the starting flawed pearls. As soon as a small proportion of these macromolecules is present, the growth of aragonite appears inhibited.

Several hypotheses can be proposed to explain the occurrence of the defect, some of which can be quickly eliminated. This defect cannot result from fragments or from foreign elements contaminating the extrapallial fluid from outside. Chemical or ionic intruders can also be eliminated because of the scale and the great reproducibility of the defect. If this were the case, the defects would occur in a more random way, similar to the foreign intruders themselves. This defect is thus connected to a tiny and reproducible disturbance. The same defect occurs in all individuals in Japan or in Chinese farming districts [34].

If we consider the different macromolecule distributions, as revealed by HPLC, and its unusual abundance, several hypotheses can be formulated. The first hypothesis suggests that a light disorder of the fluid composition secreted by the mantle is responsible of the defect. Locally, the presence of disruptive molecules provokes the allotropic change of the mineral phase ('bifurcation' hypothesis). We observed that even in small quantities, the hydrosoluble matrix provokes the exclusive growth of vaterite in vitro.

Another hypothesis consists in viewing vaterite as a transitory stage of the growth mechanism. It is a form that can be present regularly in the centre of a good-quality pearl [8]. Several authors have already suggested the existence of a transitory stage in the course of the nacre biomineralisation process, hypothesis first proposed by Towe and Hamilton [35]. For a certain number of taxa, this mechanism of biomineralisation is already established under the form of amorphous calcium carbonate [36]. Vaterite transient form has been reported in only a few instances, e.g. during molluscan shell repair or experimental growth [37] and [38]. If this hypothesis is confirmed, the presence of vaterite in the pearl would indicate that it is a transient form (of transport or deposit); in this case, the transformation of vaterite into aragonite is hampered by fixing the 'vaterite' transitory state.

The cause could be explained by a minor increase of $\mathrm{Mg}^{2+}$ and/or $\mathrm{Mn}^{2+}$ in different environments, as previously discussed by the authors [39], [40] and [34]. This hypothesis of stabilisation by a divalent ion such as $\mathrm{Mg}^{2+}$ and/or $\mathrm{Mn}^{2+}$ is in line with the strong cathodoluminescence response we observed for vaterite.

Finally, the question can also be placed on the role of twinning in aragonite and its hexagonal form nearly similar to vaterite [41]. The study of the structure and texture of vaterite is certainly a track for further studies by comparison with other pathological deposits of vaterite [9] and [10]. 


\section{Conclusions}

In this work, we propose for the first time the use of cathodoluminescence as a nondestructive technique for evaluating the presence of vaterite defects in pearls with optical microscopy resolution. This technique is more efficient and non-destructive compared to XRD [2], TEM [3] and [4] or LA/ICP/MS [8] and [34].

Cathodoluminescence was previously used to distinguish Chinese freshwater pearls [42].

The occurrence of vaterite during the growth of the pearl is completely reversible during the deposit, i.e., vaterite is frequently covered with aragonite and vice versa. Additionally, vaterite and aragonite can deposit in the same area, i.e. not exclusively from each other.

Pyrolisis (Rock-Eval) shows that milky pearls contain more organic carbon than regular pearls (approximately $20 \%$ more in mix pearl).

Only the hydrosoluble organic fraction exhibits obvious differences in the molecular distribution, as seen by HPLC. This fraction is known to concentrate intracrystalline molecules.

Controlled growth experiments conducted in the presence of the hydrosoluble fraction of the milky pearls produce vaterite crystals. Experiments conducted with the hydrosoluble fraction of regular pearls (aragonite nacre) produce aragonite and calcite crystals.

\section{Acknowledgment}

This work was supported by the NRFC and the French Research Agency (2010-INTB-990901 NanoBioCarbonate). Authors thank Dr X. Kong, Associate Professor at Zhejiang University, Hangzhou for his kind help in Zhuji. Sylvain Janiec is warmly acknowledged for his skilful plate polishing. Thanks to Li Zhuo and Claire Ramboz for their very helpful support in the experimental processes. This international collaboration was initiated thanks to the AFCRST (Association Franco-Chinoise pour la Recherche Scientifique et Technique).

\section{References}

M. Rousseau, A. Meibom, M. Geze, X. Bourrat, M. Angellier, E. Lopez

Dynamics of sheet nacre formation in bivalves

J Struct Biol, 165 (2009), pp. 190-195

H.Y. Ma, I.-S. Lee

Characterization of vaterite in low quality freshwater-cultured pearls

Mater Sci Eng C, 26 (2006), pp. 721-723

L. Qiao, Q.L. Feng, Z. Li

Special vaterite found in freshwater lackluster pearls

Cryst Growth Des, 7 (2) (2007), pp. 275-279

L. Qiao, Q.L. Feng 
Study on twin stacking faults in vaterite tablets of freshwater lacklustre pearls J Cryst Growth, 304 (1) (2007), pp. 253-256

L. Qiao, Q.L. Feng, Y. Liu

A novel bio-vaterite in freshwater pearls with high thermal stability and low dissolubility

Mater Lett, 62 (12-13) (2008), pp. 1793-1796

L. Qiao, Q.L. Feng, S.S. Lu

In vitro growth of nacre-like tablet forming: from amorphous calcium carbonate, nanostacks to hexagonal tablets

Cryst Growth Des, 8 (5) (2008), pp. 1509-1514

L. Qiao, Q.L. Feng, Z. Li, S.S. Lu

Alternate deposition of oriented calcite and amino acid layer on calcite

J Phys Chem B, 112 (43) (2008), pp. 13635-13640

A.L. Soldati, D.E. Jacob, U. Wehrmeister, W. Hofmeister

Structural characterization and chemical composition of aragonite and vaterite in freshwater cultured pearls

Mineral Mag, 72 (2008), pp. 579-592

N. Spann, E.M. Harper, D. Aldridge

The unusual mineral vaterite in shells of the freshwater bivalve Corbicula fluminea from the UK

Naturwissenschaften, 97 (2010), pp. 743-751

M. Frenzel, R.J. Harrison, E.M. Harper

Nanostructure and crystallography of aberrant columnar vaterite in Corbicula fluminea (Mollusca)

J Struct Biol, 178 (2012), pp. 8-18

D. Ren, Q.L. Feng, X. Bourrat

Effects of additives and templates on calcium carbonate mineralization in vitro Micron, 42 (2010), p. 228

L. Pereira-Mouriès, M.-J. Almeida, C. Ribeiro, J. Peduzzi, M. Barthélemy, C. Milet et al. Soluble silk-like organic matrix in the nacreous layer of the bivalve Pinctada maxima

Eur J Biochem, 269 (2002), pp. 4994-5003

V. Barbin, U. Brand, R.A. Hewitt, K. Ramseyer

Similarity in cephalopod shells biogeochemistry since Carboniferous: evidence from cathodoluminescence

Geobios, 28 (6) (1995), pp. 701-710

X. Bourrat, L. Francke, E. Lopez, M. Rousseau, P. Stempfle, M. Angellier et al.

Nacre biocrystal thermal behaviour

CrystEngComm, 9 (2007), pp. 1205-1208

A.G. Checa, A.B. Rodriguez-Navarro, F.J.E. Delgado, F.J. Esteban-Delgado 
The nature and formation of calcitic columnar prismatic shell layers in pteriomorphian bivalves

Biomaterials, 26 (32) (2005), pp. 6404-6414

S.E. Sommer

Cathodoluminescence of carbonates, 2: geological applications

Chem Geol, 9 (1-4) (1972), pp. 275-284

V. Barbin

Cathodoluminescence of carbonates shells: biochemical vs diagenetic process M. Pagel, V. Barbin, Blanc Ph, Ohnenstetter (Eds.), Cathodoluminescence in Geosciences, Springer Verlag (2000), pp. 303-329 [Chap12]

S.E. Sommer

Cathodoluminescence of carbonates, 1: characterization of cathodoluminescence from carbonate solid solutions

Chem Geol, 9 (1-4) (1972), pp. 257-273

P. Béarez, G. Carlier, J.-P. Lorand, G.-C. Parodi

Destructive and non-destructive microanalysis of biocarbonates applied to anomalous otoliths of archeological and modern scianids (Teleostei) from Peru and Chile

CR Biol, 328 (2005), pp. 243-252

J. Balmain, B. Hannoyer, E. Lopez

Fourier Transform Infrared Spectroscopy (FTIR) and X-ray diffraction analyses of mineral and organic matrix during heating of mother of pearl (nacre) from the shell of the mollusc Pinctada maxima

J Biomed Mater Res, 48 (5) (1999), pp. 749-754

J.W. Wang, U. Becker

Structure and carbonate orientation of vaterite $\left(\mathrm{CaCO}_{3}\right)$

Am Mineral, 94 (2-3) (2009), pp. 380-386

Y. Levi-Kalisman, G. Falini, L. Addadi, S. Weiner

Structure of the nacreous organic matrix of a bivalve mollusk shell examined in the hydrated sate using cryo-TEM

J Struct Biol, 135 (2001), pp. 8-17

Y. Dauphin, F. Marin

Comparison for the soluble organic matrices of healthy and diseased shells of Pinctada margaritifera (L.) and Pecten maximus L. (Mollusca, Bivalvia). J. of invertebrate

Pathology, 76 (2000), pp. 49-55

F.C. Meldrum

Calcium carbonate in biomineralisation and biomimetic chemistry

Int Mater Rev, 48 (3) (2003), pp. 187-224

N. Wada, S. Suda, K. Kanamura, T. Umegaki

Formation of thin calcium carbonate films with aragonite and vaterite forms coexisting with polyacrylic acids and chitosan membranes 
J Colloid Interface Sci, 279 (2004), pp. 167-174

Q.S. Wu, D.M. Sun, H.J. Liu, Y.P. Ding

Abnormal polymorph conversion of calcium carbonate and nano-self-assembly of vaterite by a supported liquid membrane system

Cryst Growth Des, 4 (4) (2004), pp. 717-720

F.C. Meldrum, H. Cölfen

Controlling mineral morphologies and structures in biological and synthetic systems

Chem Rev, 108 (11) (2008), pp. 4332-4432

A.W. Xu, M. Antonietti, H.Y. Cölfen, P. Fang

Uniform hexagonal plates of vaterite $\mathrm{CaCO}_{3}$ mesocrystals formed by biomimetic mineralization

Adv Funct Mater, 16 (2006), pp. 903-908

T. Hirai, S. Hariguchi, I. Komassawa

Biomimetic synthesis of calcium carbonate particles in a pseudovesicular double emulsion

Langmuir, 13 (1997), pp. 6650-6653

N. Gehrke, H. Cölfen, N. Pinna, M. Antonietti, N. Nassif

Superstructures of calcium carbonate crystals by oriented attachment

Cryst Growth Des, 5 (2005), pp. 1317-1319

G. Falini, S. Albeck, S. Weiner, L. Addadi

Control of aragonite or calcite polymorphism by mollusk shell macromolecules

Science, 271 (5245) (1996), pp. 67-69

J. Aizenberg, G. Lambert, S. Weiner, L. Addadi

Factors involved in the formation of amorphous and crystalline calcium carbonate: a study of an ascidian skeleton

J Am Chem Soc, 124 (1) (2002), pp. 32-39

S. Ouhenia, D. Chateigner, M.A. Belkhir, E. Guilmeau, C. Krauss

Synthesis of calcium carbonate polymorphs in the presence of polyacrylic acid

J Cryst Growth, 310 (2008), pp. 2832-2841

U. Wehrmeister, D.E. Jacob, A.L. Soldati, T. Häger, W. Hofmeister

Vaterite in freshwater cultured pearls from China and Japan

J Gemmol, 31 (2007), pp. 269-276

K.M. Towe, H.G. Hamilton

Ultrastructure and inferred calcification of the mature and developing nacre in bivalve mollusks

Calcif Tissue Res, 1 (1968), pp. 306-318

I.M. Weiss, N. Tuross, L. Addadi, S. Weiner

Mollusc larval shell formation: amorphous calcium carbonate is a precursor phase for aragonite

J Exp Zool, 293 (2002), pp. 478-491 
K.M. Wilbur, N. Watabe

Experimental studies on calcification in molluscs and the alga Coccolithus huxleyi Ann N Y Acad Sci, 109 (1963), pp. 82-112

A.S.M. Saleuddin, K.M. Wilbur

Shell regeneration in Helix pomatia

Can J Zool, 47 (1969), pp. 51-53

A.G. Checa, C. Jiménez-López, A. Rodríguez-Navarro, J.P. Machado Precipitation of aragonite by calcitic bivalves in $\mathrm{Mg}$-enriched marine waters Mar Biol, 150 (2007), pp. 819-827

S. Melancon, B.J. Fryer, S.A. Ludsin, J.E. Gagnon, Z.P. Yang Effects of crystal structure on the uptake of metals by lake trout (Salvelinus namaycush) otoliths

Can J Fish Aquat Sci, 62 (11) (2005), pp. 2609-2619

A. Le Bail, S. Ouhenia, D. Chateigner

Microtwinning hypothesis for a more ordered vaterite model

Powder Diffract, 26 (1) (2011), pp. 16-21

A. Banerjee, D. Habermann

Identification of Chinese fresh-water pearls using $\mathrm{Mn}^{2+}$ activated cathodoluminescence

Carbonates Evaporites, 15 (2000), pp. 138-148 